\title{
Boynunda Enfekte Kistle Başvuran Çocuk Olgu
}

Turan YILDIZ1 ${ }^{1}$, Zekeriya İLÇE ${ }^{1}$

Öz

Yayın Bilgisi

$\mathrm{Bu}$ olgu sunumunda boynunda şişlik ve üzerinde kızarık ile başvuran dört yaşındaki kız Gönderi Tarihi:27/08/2017 çocuğunu sunmayı amaçladık.

Kabul Tarihi:09/09/2017

Anahtar Kelimeler: Çocuk, Boyun, Kist

\section{Child who applied with infected cyst in his neck}

Turan YILDIZ1 ${ }^{1}$, Zekeriya ILÇE ${ }^{1}$

\begin{tabular}{l|r}
\hline Abstract & $\begin{array}{r}\text { Article Info } \\
\text { In this case report, we aimed to present a four-year-old girl with swelling and redness on } \\
\text { her neck. }\end{array}$ \\
$\begin{array}{lr}\text { Keywords: Child, Neck, Cyst. } & \text { Received:27/08/2017 } \\
\text { Accepted:09/09/2017 } \\
\text { Online Published:31/12/2017 } \\
\text { Corresponding Author } \\
\text { Turan YILDIZ }\end{array}$ \\
\hline
\end{tabular}

${ }^{1}$ Sakarya Üniversitesi Tıp Fakültesi Çocuk Cerrahisi AD, Sakarya

\section{GíRiș}

Dört yaşında kız çocuğu son 3 aydır boynunun altında şişlik olup bu şişlik üzerinde son 4 gündür kızarıklık olmuş (resim 1). Çocuğun ağrısı olmamış ancak son 3 gündür ateşi olmuş, akıntısı hiç olmamış. Bu şikayetler ile gittiği hekim tarafından ultrason yapılmış ve içeriği yoğun kistik kitle olarak tariflenmiş. Bunun üzerine hasta çocuk cerrahi polikliniğine yönlendirilmiş. Hastanın fizik muayenesinde kitle boyunda orta hattın hafif solunda idi. Üzerinde 1sı artışı, kızarıklık ve hassasiyet mevcuttu. Yutkunmakla kist hafif hareketli idi.

Bu klinik tablo için tanınız nedir?

(Yanıt İçin Tıklayınız) 


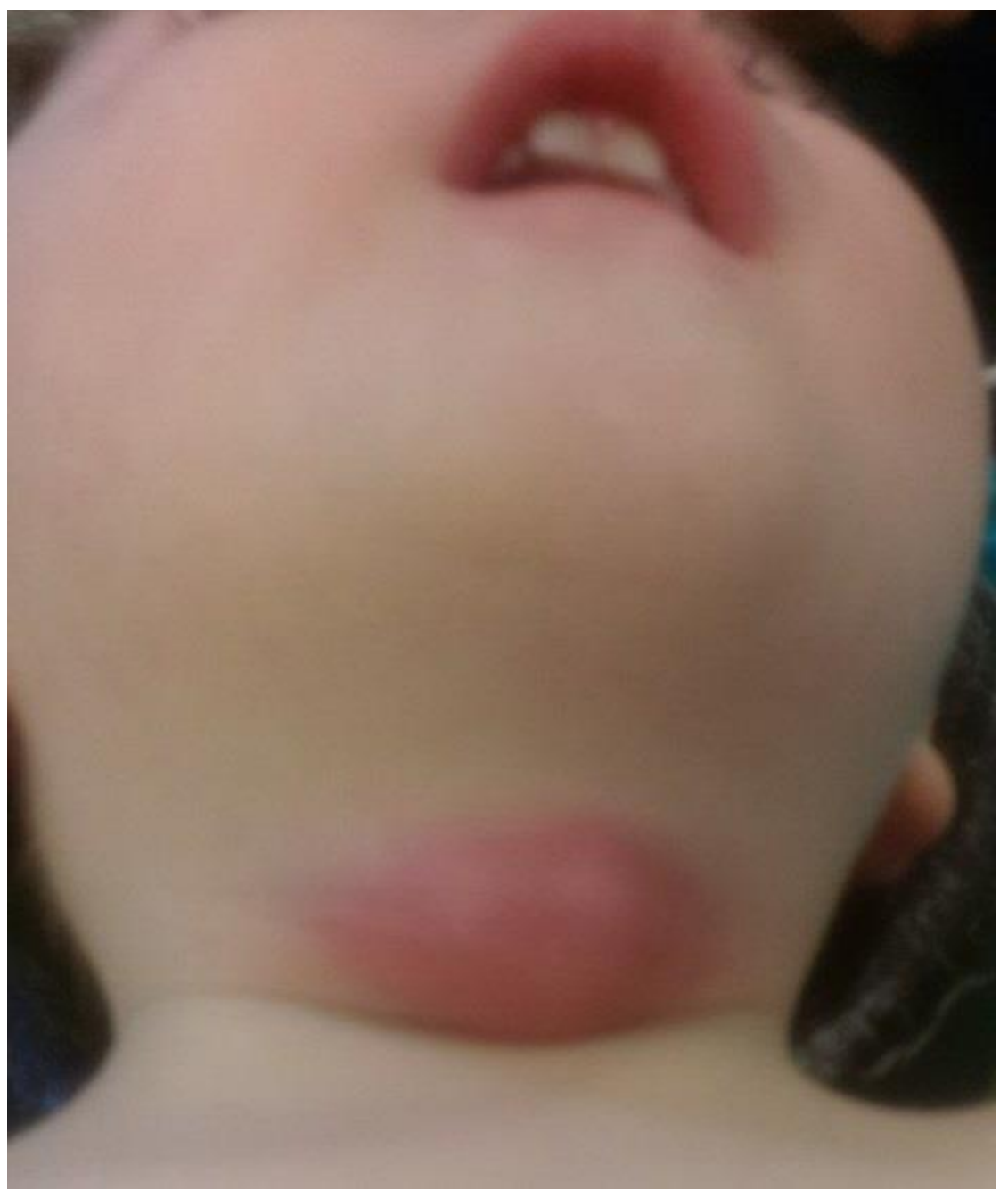

Şekil 1. Çocuğun boynunda bulunan $2 \times 3$ cmlik yumuşak kıvamlı, üzeri kızarık kitle

(Yanıt İçin Tıklayınız) 


\section{YANIT}

Tiroglossal duktus kistleri, foremen çekum ve troid gland arasındaki konjenital artıkların postnatal hayatta devam etmesi nedeni ile oluşan patolojilerdir. Zamanında tanı konulamayan veya hastaneye geç başvuran hastalar vakamızda olduğu gibi enfekte kist ile başvurabilmektedir. Daha fazla geciken vakalarda ise kist cilde fistülüze olabilmektedir. Tiroglossal duktus kisti olan vakalarda boynun orta hattında yutkunmakla hareketli kistik kitleler görülür. Ayırıcı tanıda dermoid kist, abberan troid dokusu, hemangiom, teratom düşünülmelidir. Tanı için fizik muayeneye ve ultrason sıklıkla yeterli olmakla birlikte tomografi ve sintigrafiye zaman zaman başvurulur. Enfekte olmayan kistlerin tedavisinde kistin hyoid kemik korpusu ile total olak eksizyonu (sistrunk operasyonu), enfekte olanlarda ise enfeksiyon tedavisi sonrası cerrahi tedavi sıklıkla yeterli olmaktadır. ${ }^{1,2}$

\section{KAYNAKLAR}

1. Alpay HC, Kaygusuz İ, Karlıdağ T ve ark. Tiroglossal Duktus Kist ve fistülleri: 32 vakalık bir inceleme. Firat Tıp Dergisi 2007;12(4): 287-289.

2. Açıkalın RM, Hacı C, Bayram AA, Gezginadam Z ve ark. Tiroglossal Duktus Kist ve Fistüllerindeki Klinik Sonuçlarımız. Med Bull Haseki 2016;54:94-96. 